\title{
Quantitative analysis and detection of chaptalization and watering down of wine using isotope ratio mass spectrometry
}

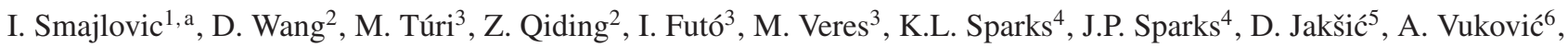 \\ and M. Vujadinović6 \\ ${ }^{1}$ SG Isotech DOO Pančevo, Maksima Gorkog 58/C, 26000 Pančevo, Republic of Serbia \\ ${ }^{2}$ C.N.R.I.F.F.I. - China National Institute of Food and Fermentation Industries Limited, Building 6, No.24, Jiuxianqiao Middle Road, \\ Chaoyang District, Beijing, People's Republic of China, Post 10015 \\ ${ }^{3}$ IZOTOPTECH LTD. Bem ter 18/C., 4026 Debrecen, Hungary \\ ${ }^{4}$ COIL (Cornell University, Stable Isotope Laboratory), Corson Hall, E149, Ithaca, NY 14853, USA \\ ${ }^{5}$ Center for Viticulture and Oenology, Bul. Kralja Aleksandra 84, Office No. 15, 11111 Belgrade, Republic of Serbia \\ ${ }^{6}$ Faculty of Agriculture, Belgrade University, Nemanjina 6, 11080 Belgrade, Republic of Serbia
}

\begin{abstract}
In early 1990's European Union has established new isotopic approach for detection of wine authenticity. In this article we setup the possibility of using new approach using new EIM - Module - IRMS (Ethanol Isotope Measurement - Module - Isotope Ratio Mass Spectrometry) instrumental technique and new analytical parameter $\delta \mathrm{D}_{\mathrm{n}}\left(\delta^{2} \mathrm{H}_{\mathrm{n}}\right)$ wine ethanol value, which represents $\delta^{2} \mathrm{H}$ value of non-exchangeable hydrogen stable isotope ratio in ethanol, with other isotopic species $\left(\delta^{18} \mathrm{O}\right.$ values in wine water) to improve detection of illegal wine production practices such as addition of sugar and/or dilution with water. Total of 42 wine samples were analyzed. 10 wine samples (out of 42) were prepared from grapes by alcoholic fermentation and analyzed for $\delta \mathrm{D}_{\mathrm{n}}$ values of ethanol. 19 wine samples (out of 42) were collected from wine producers in Serbia plus 1 wine samples designated from United States was taken from Serbian market and analyzed for $\delta D_{n}$ values of ethanol, $\delta^{18} \mathrm{O}$ values in wine water and also $\delta^{13} \mathrm{C}$ values in wine ethanol. Furthermore 9 wine samples (out of 42) were taken from Hungarian market and analyzed for $\delta D_{n}$ values of ethanol, and also 3 wine samples (out of 42) were taken from Austrian market and analyzed for $\delta \mathrm{D}_{\mathrm{n}}$ values of ethanol. All experiments were done in 4 isotope laboratories located in US, Austria, Hungary and People's Republic of China. $\delta \mathrm{D}_{\mathrm{n}}$ values of ethanol were measured by using EIM Module connected to FlashHT 2000 pyrolizer (one laboratory - Imprint Analytics GmbH, Austria), while in other 3 laboratories (US - COIL Cornell University, Stable Isotope Laboratory, Hungary - Isotoptech Ltd, Debrecen, Hungary and China C.N.R.I.F.F.I. - China National Institute of Food and Fermentation Industries Limited) EIM Module was connected to TC/EA (High Temperature Conversion Elemental Analyzer). Peripherals in all laboratories were further interfaced with isotope ratio mass spectrometer. Furthermore $\delta^{18} \mathrm{O}$ values in wine water were measured by using Gas Bench II interfaced also with isotope ratio mass spectrometer (one laboratory - US). Obtained results from all 4 laboratories have shown that this new approach which uses $\delta D_{n}$ in wine ethanol is more effective in improving detection of illegal wine production practices (sugar enrichment and water dilution) and origin of ethanol, and also detecting the addition of corn or beet sugar, sugar syrup to wine, or dilution of grape must with water prior to alcoholic fermentation.
\end{abstract}

Keywords: Wine authenticity; EIM - Module - IRMS; Stable Isotope; Isotope Ratio Mass Spectrometry; Wine; Watering; Chaptalization.

\section{Introduction}

The EU is the largest wine producer in the world, accounting for about two thirds of global production according to the European Commission's DirectorateGeneral of Agriculture and Rural Development. Of the estimated 22.6 million tones of grapes produced in the EU-28 in 2014, the vast majority (93\%) was destined for wine production. Italy, Spain and France were the principal wine grape producers in the EU. (Eurostat statistical books, 2015 edition) Wine production in NWC (New World Countries) such as Chile, New Zealand,

a e-mail: ivan@sgisotech.com
Australia, South Africa and US has increased over the last 20 years and became very competitive with wine production in Europe. This fact was a turning point for the European Commission to raise the issue for the reform of the European wine sector, so that European wine could respond to the challenge and become more competitive on the World market. EU wine reform raised up some new demands for measures which would strengthen EU wine sector. These measures among other things contained new rules for grabbing-up scheme followed by regulations on planting rights, phasing-out of distillation schemes, new labeling rules and also approving of some new wine-making practices, or changing existing ones (Giulia Meloni and Johan Swinnen, 2012). 
At the same time, among other things, climate change and global warming are strongly affecting world's wine industry. This global climate change is even more obvious in NWC. This fact has consequences for obtaining grapes with higher sugar content (in recent years very often sugar content in grapes was even more than $250 \mathrm{~g} / \mathrm{L}$ ), which often give final wine with unfermented sugar (semi-dry or semi-sweet), or sometimes wine which is strong in alcohol, but without body and empty in taste. Unfortunately, such wine is not so desired by the end consumers, and its preservation requires additional efforts in technological or chemical sense. With addition of water to grape must prior to alcoholic fermentation, sugar concentration in grape must can be diluted, which would ensure the production of dry wine, but this production practice is forbidden in almost all the countries in the World, since it would be misused and give higher quantities of wine and open the door to all kinds of other adulterations which are not so easily to track.

It is worth remembering that the addition of sugar to grape must, prior to or during alcoholic fermentation, can be legal. According to EU Regulation 479/2008 (Annex V) it is emphasized that: "Where climatic conditions have made it necessary in certain wine-growing zones of the Community referred to in Annex IX, the Member States concerned may allow to supplement the natural alcoholic strength by volume of fresh grapes, grape must, grape must in fermentation, new wine still in fermentation and wine obtained from wine grape varieties classifiable according to Article 24(1)". The same EU Regulation also states that the increase in natural alcoholic strength by volume can only be effected by adding sucrose (in dry), concentrated grape must or rectified concentrated grape must. Also all authorized oenological practices shall exclude the addition of water, except where required on account of a specific technical necessity.

On the other hand, according to US Regulation, generally, addition of water and sugar is permitted for wine must and wine in most of the US states (27 CFR $\S 24.178$ and $\$ 24.181)$. However some states, California for example, may have different and stricter regulations where addition of sugar and/or water is not allowed as such. Several aspects, like geographical origin, year of vintage, grape cultivar and quality, are involved in authentication of wine. Origin-specific parameters which do not undergo alterations during vinification or which are difficult to adulterate are perfect for authentication of wine. Multiisotopic and/or multi-component analysis allows reliable assessment of the authenticity of wine. (Rossmann, 2001; Kelly, Heaton \& Hoogewerff, 2005; Calderone, Guillou, 2008).

With all ongoing problems which are affecting wine industry in the EU, quality control has become even more important than ever. In 1990's EU has introduced regulations on authenticity control of wine and spent billions of euros to build up the system of the national reference laboratories for detection of illegal wine production practices and protection of European wine with designated origin. First officially adopted stable isotope method for the analysis of wine in EU was determination of the site-specific D/H ratio by NMR for wine ethanol which mainly provides evidence of the addition of beet sugar. NMR and/or Isotope Ratio Mass Spectrometry determinations provide information on the botanical and geographical origins, which are often considered, by consumers and regulations, as important characteristics of food products. (Martin G.J. 1983, Hoogewerff, 2005., Calderone, Guillou, 2008).

With regard to the detection of water addition, this is determined on the basis of analysis of the isotopic ratio ${ }^{18} \mathrm{O} /{ }^{16} \mathrm{O}$ (expressed as $\delta^{18} \mathrm{O} \%$ ) of wine water and the comparison of this value with the reference data defined by the official wine data-bank (EU Regulation 555/2008).

Still, with those official EU isotopic methodologies, there is a very small possibility to detect illegal watering or illegal chaptalization of wine which is importing into EU or other countries in the World (China or US), since it would be very hard to collect the grape samples for isotopic data bank to be used for comparison with official samples coming from the borders.

It has been shown previously that addition of water causes a detectable decrease in the original $\delta^{18} \mathrm{O}$ value in wine. The main reason for this decrease is the fact that botanical water contained in wine has a $\delta^{18} \mathrm{O}$ value which is much higher than tap water as a consequence of the evapotranspiration processes occurring in plants (Rossmann and others 1999). Isotope fractionation of oxygen occurs with processes of evaporation and condensation of the water cycle. Evaporation of water results in a decrease in heavier isotopes in the vapor. The degree of fractionation depends on temperature. (Calderone \& Guillou, 2008).

Ground water, which is the main factor that affects $\delta^{18} \mathrm{O}$ in plant water, is influenced by climatic conditions of a location, which already influence precipitation and additionally modify transpiration of leaves. Due to $\delta^{18} \mathrm{O}$ enrichment of plant water, in comparison to ground water, analysis of $\delta^{18} \mathrm{O}$ of wine water have been used for detection of watering down of wine. Lower values of $\delta^{18} \mathrm{O}$ of water in wines may indicate exogenous addition of water, but it can also be result of high rainfall during the harvest of grapes. The analysis of $\delta^{18} \mathrm{O}$ in wine water is well accepted in European Union. Its purpose, besides the detection of addition of water, is to support geographical origin. (Rossman et al., 1999, EC Regulation 822/97, Dunbar J., 1982). But, if the starting wine is originally characterized by high $\delta^{18} \mathrm{O}$, detection of the addition of a small percentage of water is not easy (Matteo Perini and Federica Camin, 2013). Previously it has been suggested that there is a strong relationship between the $\delta^{18} \mathrm{O}$ value of fermentation water and ethanol (Jamin et al., 2003). Exogenous addition of water during or after alcoholic fermentation would disrupt this correlation between $\delta^{18} \mathrm{O}$ values of ethanol and wine water, and would be detected as such. In our previous work, we presented EIM-IRMS ${ }^{\circledR}$ (Ethanol Isotopic Measurement - Isotope Ratio Mass Spectrometry) method for determination of origin of wine and determination of addition of sugar and addition of water for wine with geographical indications. Isotopic parameter $\delta D_{n}$ value of wine ethanol has been proposed. It represents $\delta$ value of non-exchangeable hydrogen and deuterium atoms of ethanol. Since non-exchangeable hydrogen stable isotopes in ethanol carry information about botanical origin and also information about the conditions during alcoholic fermentation (type of water used during fermentation), we have shown that with this approach it would be possible to detect both illegal practices as such (Ivan Smajlovic et al., 2012). 
Table 1. Authentic samples and samples with addition of Beet sugar and addition of water prior to alcoholic fermentation.

\begin{tabular}{|c|c|c|c|c|c|}
\hline Sample & $\begin{array}{l}\text { Sample } \\
\text { number }\end{array}$ & Authentic & $\begin{array}{l}\text { Dilution with water prior to } \\
\text { alcoholic fermentation } \\
\qquad(20 \% \mathrm{v} / \mathrm{v})\end{array}$ & $\begin{array}{l}\text { Addition of Beet sugar } \\
\text { to grape must prior to } \\
\text { alcoholic fermentation } \\
\qquad(30 \mathrm{~g} / \mathrm{L})\end{array}$ & $\begin{array}{c}\text { Addition of Beet sugar } \\
\text { to grape must prior to } \\
\text { alcoholic fermentation } \\
(20 \mathrm{~g} / \mathrm{L})\end{array}$ \\
\hline \multirow{3}{*}{$\begin{array}{l}\text { Grape no.1 } \\
\text { Sugar concentration: } \\
125 \mathrm{~g} / \mathrm{L}\end{array}$} & DB73-01 & $\checkmark$ & & & \\
\hline & DB73-02 & & & $\begin{array}{c}\checkmark \\
\text { (21 g of Beet sugar into } \\
700 \mathrm{~mL} \text { of grape must) }\end{array}$ & \\
\hline & \begin{tabular}{|l|} 
DB73-03 \\
DB73-03
\end{tabular} & & $\begin{array}{c}\checkmark \\
(140 \mathrm{~mL} \text { of tap water }+560 \mathrm{~mL} \\
\text { of grape must })\end{array}$ & & \\
\hline \multirow{4}{*}{$\begin{array}{l}\text { Grape no.2 } \\
\text { Sugar concentration: } \\
160 \mathrm{~g} / \mathrm{L}\end{array}$} & DB73-04 & $\checkmark$ & & & \\
\hline & DB73-05 & & & $\begin{array}{c}\checkmark \\
(29.4 \mathrm{~g} \text { of Beet sugar into } 700 \mathrm{~mL} \\
\text { of grape must) }\end{array}$ & \\
\hline & DB73-06 & & $\begin{array}{c}\checkmark \\
\left(\begin{array}{c}(140 \mathrm{~mL} \text { of tap water }+560 \mathrm{~mL} \\
\text { of grape must })\end{array}\right.\end{array}$ & & \\
\hline & DB73-07 & & & & $\begin{array}{c}\checkmark \\
\text { (14 g of Beet sugar } \\
\text { into } 700 \mathrm{~mL} \\
\text { of grape must) }\end{array}$ \\
\hline \multirow{3}{*}{$\begin{array}{l}\text { Grape no. } 3 \\
\text { Sugar concentration: } \\
120 \mathrm{~g} / \mathrm{L}\end{array}$} & DB73-08 & $\checkmark$ & & & \\
\hline & DB73-09 & & & $\begin{array}{c}\checkmark \\
\text { (21 g into } 700 \mathrm{~mL} \text { of } \\
\text { Beet sugar grape must) }\end{array}$ & \\
\hline & DB73-10 & & $\begin{array}{c}\checkmark \\
(140 \mathrm{~mL} \text { of tap water }+560 \mathrm{~mL} \\
\text { of grape must })\end{array}$ & & \\
\hline
\end{tabular}

EIM - IRMS ${ }^{\circledR}$ method has been standardized and has become a source document of the Institute for Standardization of the Republic of Serbia, and subsequently accepted by the technical committee of the Ministry of Agriculture of the Republic of Serbia and became a part of the official wine regulation of the Republic of Serbia (Regulation on the parameters and methods for analysis and quality assurance of grape, wine and other products of grapes, grape must, pomace and wine used in wine production ("Official Gazette RS" No.107/2014).

In this paper, we presented and discussed results of $\delta \mathrm{D}_{\mathrm{n}}$ values in ethanol from wine $(N=42)$, in correlation with results obtained for $\delta^{13} \mathrm{C}$ in wine ethanol and $\delta^{18} \mathrm{O}$ from wine water. 10 wine samples were prepared from Chinese grapes by controlled alcoholic fermentation where some of the samples were fermented as authentic without any addition $(N=3)$, while others were chaptalized or diluted with water. The additional 33 wine samples from different varieties, vintages, and location were collected from Serbian wine producers $(N=19)$ and United States wine producers $(N=1)$, and the rest were taken from Hungarian $(N=9)$ and Austrian $(N=3)$ market. We studied the dependence between $\delta D_{n}$ ethanol values and the addition of sugar or water and also the relationships between $\delta \mathrm{D}_{\mathrm{n}}$ ethanol values and $\delta^{18} \mathrm{O}$ values of wine water in order to verify the ability to better differentiate and detect weather if wine was chaptalized or diluted with water.

\section{Materials and methods}

\subsection{Samples}

A total of $N=42$ wine samples were considered. First 10 wine samples were prepared at China National Institute for Food and Fermentation Industries Limited (C.N.R.I.F.F.I.) from three different Chinese grapes by controlled alcoholic fermentation where some of the samples were fermented as authentic without any addition $(N=3)$, while others were chaptalized $(N=4)$ or diluted with water $(N=3)$. These first 10 samples were used for the estimation of the repeatability from in-house repeatability studies performed in 3 participating laboratories (Imprint Analytics $\mathrm{GmbH}-$ Austria, Isotoptech LTD in Debrecen - Hungary and C.N.R.I.F.F.I. - People's Republic of China), so that it could provide data that would allow the estimation of the repeatability of the EIM - Module - IRMS method.

Furthermore, wine samples $(N=19)$ were collected from Serbian wine producers from 5 different locations and vintages and one more wine sample from US, California, was taken from Serbian market and tested. Additionally 9 more wine samples were collected from Hungarian market and additional 3 wine samples were taken from Austrian market. 
Table 2. Wine samples results from Imprint Analytics GmbH.

\begin{tabular}{|l|c|c|c|c|c|c|c|c|}
\hline \multicolumn{7}{|c|}{ Ethanol $\delta \mathbf{D}_{\mathbf{n}}$ values } \\
\hline & 13.09 vs. AAWES at SGI Scale) \\
\hline & Mean & St.Dev.* & Mean & St.Dev.* & Mean & St.Dev.* & Mean & St.Dev.* \\
\hline DB73-01 & -214.16 & 1.41 & -214.96 & 0.76 & - & - & -213.54 & 0.48 \\
\hline DB73-02 & -220.34 & 0.95 & -221.14 & 0.52 & -223.85 & 1.34 & -224.32 & 0.90 \\
\hline DB73-03 & - & - & -218.71 & 1.28 & -218.15 & 2.62 & -218.05 & 1.20 \\
\hline DB73-04 & -211.71 & 0.50 & -212.25 & 3.51 & -211.64 & 1.62 & -213.43 & 0.40 \\
\hline DB73-05 & -220.39 & 2.38 & -220.41 & 0.80 & -220.45 & 1.13 & -219.85 & 1.44 \\
\hline DB73-06 & - & - & -220.74 & 1.38 & -219.78 & 2.44 & -217.85 & 0.34 \\
\hline DB73-07 & -214.79 & 1.25 & -214.37 & 0.43 & -216.06 & 0.09 & -216.21 & 1.12 \\
\hline DB73-08 & -216.11 & 0.82 & -215.56 & 1.76 & - & - & -216.08 & 1.06 \\
\hline DB73-09 & -220.27 & 0.55 & -220.13 & 0.83 & -221.89 & 2.55 & -221.30 & 0.51 \\
\hline DB73-10 & -222.85 & 0.34 & -223.71 & 0.75 & -223.54 & 0.98 & -224.58 & 0.87 \\
\hline *Repeatability standard deviation of minimum 4 injection runs of the same sample. \\
\hline
\end{tabular}

Table 3. Wine samples results from Izotoptech Ltd. in Debrecen, Hungary.

\begin{tabular}{|c|c|c|c|c|c|c|c|c|c|c|c|c|}
\hline \multicolumn{13}{|c|}{ Ethanol $\delta D_{n}$ values (\%o vs. AAWES at SGI Scale) } \\
\hline & \multicolumn{2}{|c|}{ 27.09.2018. } & \multicolumn{2}{|c|}{28.09 .2018 . } & \multicolumn{2}{|c|}{ 29.09.2018. } & \multicolumn{2}{|c|}{30.09 .2018 . } & \multicolumn{2}{|c|}{01.10 .2018}$. & \multicolumn{2}{|c|}{02.10 .2018 . } \\
\hline & Mean & St.Dev.* & Mean & St.Dev.* & Mean & St.Dev.* & Mean & St.Dev.* & Mean & St.Dev.* & Mean & St.Dev.* \\
\hline DB73-01 & -214.88 & 1.63 & -214.56 & 0.81 & -214.19 & 1.78 & -214.33 & 1.45 & -213.50 & 1.76 & -214.47 & 1.29 \\
\hline DB73-02 & -221.13 & 2.25 & -221.73 & 1.28 & -220.44 & 0.89 & -220.44 & 0.77 & -218.18 & 0.29 & -218.99 & 0.43 \\
\hline DB73-03 & -218.98 & 1.87 & -217.17 & 1.25 & -217.53 & 0.85 & -218.08 & 0.20 & -218.07 & 0.81 & -216.31 & 0.81 \\
\hline DB73-04 & -213.84 & 3.86 & -214.21 & 1.01 & -212.88 & 0.17 & -213.15 & 1.42 & -214.65 & 1.09 & -214.20 & 1.11 \\
\hline DB73-05 & -219.84 & 3.79 & -220.73 & 0.94 & -219.68 & 0.59 & -220.16 & 0.63 & -220.35 & 1.76 & -220.09 & 1.32 \\
\hline DB73-06 & -219.09 & 0.60 & -214.86 & 0.77 & -216.49 & 0.93 & -217.55 & 0.53 & -216.95 & 0.61 & -216.09 & 0.29 \\
\hline DB73-07 & -220.97 & 1.25 & -215.99 & 1.12 & -216.25 & 1.47 & -215.44 & 1.00 & -215.57 & 0.94 & -214.97 & 0.44 \\
\hline DB73-08 & -216.36 & 0.07 & -214.53 & 2.13 & -218.48 & 0.88 & -216.58 & 2.41 & -216.97 & 1.26 & -216.84 & 0.27 \\
\hline DB73-09 & -224.42 & 0.42 & -221.53 & 0.28 & -220.80 & 1.07 & -220.40 & 1.04 & -220.49 & 0.64 & -219.29 & 0.30 \\
\hline DB73-10 & -224.10 & 2.03 & -219.85 & 0.88 & -220.34 & 0.48 & -220.34 & 0.48 & -220.54 & 0.46 & -219.90 & 0.91 \\
\hline
\end{tabular}

\subsection{Sample preparation}

Grape from three different varieties from China were first divided into 3 to 4 parts (total of $N=10$ ). The first parts were fermented as a control samples without any addition, while the other parts were prepared with addition of Beet sugar or addition of water as presented in Table 1.

Further, 9 wine samples from Hungarian market were prepared and tested on $\delta \mathrm{D}_{\mathrm{n}}$ values in wine ethanol (Table 7).

Also 3 more wine samples were tested on $\delta \mathrm{D}_{\mathrm{n}}$ values in wine ethanol (Table 8) - tests performed at Imprint Analytics GmbH.

Furthermore, 19 wine samples from different varieties, regions and vintages which were provided by Serbian wine producers and also one Californian wine taken from Serbian market were also tested on $\delta \mathrm{D}_{\mathrm{n}}$ values in ethanol, $\delta^{18} \mathrm{O}$ values in wine water and $\delta^{13} \mathrm{C}$ values in wine ethanol (Table 9) - tests performed at Cornell.

10 wine samples out of total $N=42$ were quantitatively fermented under controlled and standard conditions in order to achieve full conversion of sugar to ethanol (at least $98 \%$ of the theoretical yield). Other samples 32 out of 42 were obtained as final bottled wine samples.

Further, ethanol from all wine samples $(N=42)$ was extracted by distillation to obtain 90 to $94 \% \mathrm{v} / \mathrm{v}$ with recovery of minimum $90 \% \mathrm{~m} / \mathrm{m}$. For the determination of $\delta \mathrm{D}_{\mathrm{n}}\left(\delta^{2} \mathrm{H}_{\mathrm{n}}\right)$ and $\delta^{13} \mathrm{C}$ values in ethanol samples were used as such. Small aliquot of each fermented wine sample was put aside for determination of $\delta^{18} \mathrm{O}$ values in wine water.

\subsection{Isotopic measurements}

\subsection{1. $\delta^{13} \mathrm{C}$ determination in wine ethanol}

$\delta^{13} \mathrm{C}$ values were measured in ethanol obtained by distillation of wine samples. $\delta^{13} \mathrm{C}$ analysis, by mass spectrometry, is measured in $\mathrm{CO}_{2}$ produced from excess oxygen combustion of ethanol obtained by distillation. For measuring isotopic ratios of carbon $\left({ }^{13} \mathrm{C} /{ }^{12} \mathrm{C}\right)$, the technique of mass spectrometry with a double collector was used.

Isotopic ratios were measured by the simultaneous measurement of three ion beams $\left({ }^{12} \mathrm{C}^{16} \mathrm{O}^{16} \mathrm{O}^{+}\right.$, 
Table 4. Wine samples results from C.N.R.I.F.F.I. (China National Research Institute for Food and Fermentation Industries Ltd).

\begin{tabular}{|c|c|c|c|c|c|c|c|c|c|c|c|c|c|c|}
\hline \multicolumn{15}{|c|}{ Ethanol $\delta D_{n}$ values (\%o vs. AAWES at SGI Scale) } \\
\hline & \multicolumn{2}{|c|}{ 21.07.2018. } & \multicolumn{2}{|c|}{ 11.10.2018. } & \multicolumn{2}{|c|}{ 15.10.2018. } & \multicolumn{2}{|c|}{ 17.10.2018. } & \multicolumn{2}{|c|}{ 18.10.2018. } & \multicolumn{2}{|c|}{20.10 .2018 . } & \multicolumn{2}{|c|}{ 23.07.2018. } \\
\hline & Mean & St.Dev.* & Mean & St.Dev.* & Mean & St.Dev.* & Mean & St.Dev.* & Mean & St.Dev.* & Mean & St.Dev.* & Mean & St.Dev.* \\
\hline DB73-01 & -214.50 & 1.84 & -215.00 & 0.66 & -214.07 & 0.77 & -214.68 & 1.13 & -213.32 & 0.62 & -215.78 & 0.20 & -215.16 & 0.14 \\
\hline DB73-02 & -218.50 & 0.47 & -221.64 & 0.93 & -220.64 & 0.89 & -220.89 & 0.86 & -220.69 & 0.52 & -220.27 & \begin{tabular}{l|l}
7 & 0.79
\end{tabular} & -220.64 & 0.41 \\
\hline DB73-03 & -225.60 & 0.42 & -218.87 & 0.41 & -217.16 & 0.40 & -217.28 & 1.03 & -215.64 & 0.19 & -217.81 & 1.57 & -217.05 & \begin{tabular}{|l|l|}
5 & 0.16 \\
\end{tabular} \\
\hline DB73-04 & -212.40 & 0.70 & -215.13 & 1.75 & -212.07 & 0.44 & -21 & 0.46 & -213.11 & 0.62 & -212.09 & 0.48 & -212.72 & 0.81 \\
\hline DB73-05 & -22 & 1.33 & -222.49 & 0.72 & -219.67 & 0.46 & -220.38 & 0.53 & -219.70 & 0.26 & -219.36 & $\begin{array}{l}5.15 \\
5\end{array}$ & -220.30 & 0.83 \\
\hline DB73-06 & -225.30 & 0.80 & -218.36 & 0.12 & -215.68 & 0.47 & -216.12 & 0.49 & -216.37 & 0.35 & -217.06 & \begin{tabular}{|l|}
5.32 \\
\end{tabular} & -217.14 & 0.37 \\
\hline DB73-07 & -216.40 & 1.71 & -219.03 & 1.08 & -217.51 & 1.36 & -216.05 & \begin{tabular}{|l|l}
0.79 \\
\end{tabular} & -217.80 & 0.50 & -217.83 & \begin{tabular}{|l|l|}
3 & 0.57
\end{tabular} & -217.57 & \begin{tabular}{|l|l|}
7 & 0.48
\end{tabular} \\
\hline DB73-08 & -215.40 & 0.70 & -216.60 & 0.66 & -215.51 & 0.74 & -215.37 & 0.68 & -214.77 & 0.50 & -216.57 & 0.15 & -216.77 & \begin{tabular}{l|l|}
7 & 0.52 \\
\end{tabular} \\
\hline DB73-09 & -223.10 & 0.01 & -220.87 & 0.97 & -220.81 & 0.58 & -221.07 & 0.60 & -220.62 & 0.55 & -220.71 & 0.42 & -220.83 & \begin{tabular}{|l|l|}
3 & 0.42 \\
\end{tabular} \\
\hline DB73-10 & -220.20 & 1.23 & -220.81 & 0.23 & -221.08 & \begin{tabular}{|l|l|}
3 & 0.53 \\
\end{tabular} & -221.12 & 0.48 & -220.62 & 0.77 & -220.48 & \begin{tabular}{|l|l|}
3 & 0.61 \\
\end{tabular} & -221.00 & \begin{tabular}{|l|l|}
0 & 1.26 \\
\end{tabular} \\
\hline
\end{tabular}

Table 5. Ethanol $\delta \mathrm{D}_{\mathrm{n}}$ comparative results from three laboratories.

\begin{tabular}{|c|c|c|c|c|c|c|c|c|c|c|}
\hline & & \multicolumn{3}{|c|}{\begin{tabular}{|c|} 
Lab 1 (Imprint Analytics \\
GmbH)
\end{tabular}} & \multicolumn{3}{|c|}{$\begin{array}{l}\text { Lab } 2 \text { (Izotoptech Ltd.) } \\
\text { in Debrecen, Hungary) }\end{array}$} & \multicolumn{3}{|c|}{ Lab 3 (C.N.R.I.F.F.I.) } \\
\hline & & $\begin{array}{l}\text { Ethanol } \delta \mathrm{D}_{\mathrm{n}} \\
\text { mean value * }\end{array}$ & $\mathrm{sR}^{* *}$ & $\mathrm{Sr}^{* * *}$ & $\begin{array}{l}\text { Ethanol } \delta \mathrm{D}_{\mathrm{n}} \\
\text { mean value * }\end{array}$ & $s R^{* *}$ & $\mathrm{Sr}^{* * * *}$ & $\begin{array}{l}\text { Ethanol } \delta \mathrm{D}_{\mathrm{n}} \\
\text { mean value } *\end{array}$ & $\mathrm{sR}^{* *}$ & $\mathrm{Sr}^{* * *}$ \\
\hline Authentic & DB73-01 & -214.22 & 0.71 & 0.88 & -214.32 & 0.47 & 1.45 & -214.64 & 0.79 & 0.76 \\
\hline $30 \mathrm{~g} / \mathrm{L}$ Beet Sugar & DB73-02 & -222.41 & 1.97 & 0.93 & -220.15 & 1.33 & 0.98 & -220.02 & 2.08 & 0.73 \\
\hline $20 \%$ v/v water dilution & DB73-03 & -218.30 & 0.35 & 1.70 & -217.69 & 0.91 & 0.97 & -218.49 & 3.28 & 0.60 \\
\hline Authentic & DB73-04 & -212.26 & 0.83 & 1.51 & -213.82 & 0.68 & 1.44 & -212.97 & 1.06 & 0.75 \\
\hline $30 \mathrm{~g} / \mathrm{L}$ Beet Sugar & DB73-05 & -220.27 & 0.28 & 1.44 & -220.14 & 0.37 & 1.50 & -220.73 & 1.50 & 0.61 \\
\hline $20 \% \mathrm{v} / \mathrm{v}$ water dilution & DB73-06 & -219.46 & 1.47 & 1.39 & -216.84 & 1.43 & 0.62 & -218.01 & 3.33 & 0.43 \\
\hline $20 \mathrm{~g} / \mathrm{L}$ Beet Sugar & DB73-07 & -215.36 & 0.92 & 0.72 & -216.53 & 2.22 & 1.04 & -217.46 & 0.99 & 0.92 \\
\hline Authentic & DB73-08 & -215.92 & 0.31 & 1.21 & -216.63 & 1.27 & 1.17 & -216.30 & 1.23 & 0.53 \\
\hline $30 \mathrm{~g} / \mathrm{L}$ Beet Sugar & DB73-09 & -220.90 & 0.84 & 1.11 & -221.16 & 1.76 & 0.62 & -221.14 & 0.87 & 0.63 \\
\hline $20 \% \mathrm{v} / \mathrm{v}$ water dilution & DB73-10 & -223.67 & 0.71 & 0.73 & -220.84 & 1.62 & 0.87 & -220.76 & 0.34 & 0.73 \\
\hline Average & & & 0.84 & 1.16 & & 1.21 & 1.07 & & 1.55 & 0.67 \\
\hline
\end{tabular}

${ }^{13} \mathrm{C}^{16} \mathrm{O}^{16} \mathrm{O}^{+},{ }^{13} \mathrm{C}^{16} \mathrm{O}^{18} \mathrm{O}^{+}$) and by comparing the sample to a standard. For expressing the relative difference between isotopic ratios of sample and reference gas (standard), $\delta^{13} \mathrm{C}$ is used, which is defined as:

$$
\delta^{13} C(\% 0)=\left[\left(R_{\text {sample }}-R_{\text {standard }}\right) / R_{\text {standard }}\right] \times 10^{3}
$$

Where $R_{\text {standard }}$ is the absolute isotopic ratio $\left({ }^{13} \mathrm{C} /{ }^{12} \mathrm{C}\right)$ of an international standard for carbon, and it represents $R=$ 0.0112372. By international convention, $\delta^{13} \mathrm{C}$ is always expressed in relation to the value for the standard of calcium carbonate, known as PDB. This standard is a carbonate obtained from the Belemnitella Americana fossil. The base of PDB scale is the value $\delta^{13} \mathrm{C}=0 \%$ for this standard. $\delta^{13} \mathrm{C}$ value indicates if sample has a greater $(+)$ or lower $(-){ }^{13} \mathrm{C} /{ }^{12} \mathrm{C}$ ratio than PDB.

The measurement of the ${ }^{13} \mathrm{C} /{ }^{12} \mathrm{C}$ of ethanol was performed using a Continuous Flow technique using a Carlo Erba Elemental Analyzer directly interfaced to Delta V Advantage IRMS using an open split.

\subsection{2. $\delta^{18} \mathrm{O}$ determination in wine water}

${ }^{18} \mathrm{O} /{ }^{16} \mathrm{O}$ values in wine waters were determined by Gas Bench II coupled to Delta V Advantage. Using a disposable syringe, $500 \mu \mathrm{L}$ of sample was added into the open $10 \mathrm{ml}$ screwcap Exatainers, and then sealed with new septa. Residual air in the vials is removed from the sample vials by an automated auto sampler - assisted flushing procedure (PAL Loader), which uses a mixture of $0.5 \% \mathrm{CO}_{2}$ in He. Flushing is carried out at a flow of $100 \mathrm{ml} / \mathrm{min}$ for 8 minutes. $0.5 \% \mathrm{CO}_{2}$ in the flushing He stream is used as equilibration gas (Eq. (2)) (Epstein, Mayeda, 1953). Water vapor is quantitatively removed on-line from the gas stream. Measurement is carried out after an equilibration time of $24 \mathrm{~h}$ at $24^{\circ} \mathrm{C}$. The sampling loop aliquots were repetitively injected into an isothermal gas chromatograph (GC column PoraPLOT Q $25 \mathrm{~m}$, $t=24{ }^{\circ} \mathrm{C}$ ), where $\mathrm{CO}_{2}$ is separated from any other gas species. The signal intensities at $\mathrm{m} / \mathrm{z} 44,45$ and 46 were measured on the Delta V Advantage mass spectrometer 
Table 6. Inter-laboratory repeatability and reproducibility precision limits.

\begin{tabular}{|c|c|c|c|c|c|}
\hline & & Sample Number & Ethanol $\delta D_{n}$ mean value * & $\mathbf{s R}^{* *}$ & $\mathbf{s r}^{* * *}$ \\
\hline 1. & Authentic & DB73-01 & -214.39 & 0.22 & 1.03 \\
\hline 2. & $30 \mathrm{~g} / \mathrm{L}$ Beet Sugar & DB73-02 & -220.86 & 0.36 & 0.97 \\
\hline 3. & $20 \%$ v/v water dilution & DB73-03 & -218.16 & 0.42 & 1.09 \\
\hline 4. & Authentic & DB73-04 & -213.02 & 0.78 & 1.23 \\
\hline 5. & 30 g/L Beet Sugar & DB73-05 & -220.38 & 0.31 & 1.18 \\
\hline 6. & $20 \% \mathrm{v} / \mathrm{v}$ water dilution & DB73-06 & -218.10 & 1.31 & 0.81 \\
\hline 7. & 20 g/L Beet Sugar & DB73-07 & -216.45 & 1.05 & 0.89 \\
\hline 8. & Authentic & DB73-08 & -216.28 & 1.34 & 0.88 \\
\hline 9. & 30g/L Beet Sugar & DB73-09 & -221.07 & 0.15 & 0.79 \\
\hline 10. & $20 \%$ v/v water dilution & DB73-10 & -221.76 & 1.66 & 0.78 \\
\hline \multicolumn{4}{|c|}{ Average } & 0.76 & 0.97 \\
\hline \multicolumn{6}{|c|}{${ }^{*}$ Expressed in \%o vs. AAWES at SGI Scale. } \\
\hline \multicolumn{6}{|c|}{$\begin{array}{l}{ }^{* *} \mathrm{sR}-\text { Inter-laboratory Reproducibility standard deviation as Standard deviation of all measurements of the same sample } \\
\text { expressed in } \%\end{array}$} \\
\hline \multicolumn{6}{|c|}{${ }^{* * *}$ sr - Inter-laboratory Repeatability standard deviation as average standard deviation for the same sample expressed in $\%$} \\
\hline \multicolumn{6}{|c|}{ Precision limits } \\
\hline \multicolumn{3}{|c|}{$\mathrm{r}$ - Repeatability precision limit $(2.8 \times \mathrm{sr})$} & \multicolumn{3}{|c|}{2.7} \\
\hline \multicolumn{3}{|c|}{$\mathrm{R}$ - Reproducibility precision limit $(2.8 \times \mathrm{sR})$} & \multicolumn{3}{|c|}{2.13} \\
\hline \multicolumn{3}{|c|}{ Authenticity limit (A.L.) } & \multicolumn{3}{|c|}{-217.7} \\
\hline
\end{tabular}

(Thermo Scientific). The $\delta^{18} \mathrm{O}$ value, calculated by Eq. (3), is related to the international standard V-SMOW. Working standards (ultra-pure, sea and snow water) were calibrated against the V-SMOW and SLAP standards.

$$
\begin{gathered}
\mathrm{C}^{16} \mathrm{O}_{2(\mathrm{~g})}+\mathrm{H}_{2}^{18} \mathrm{O}_{(l)} \leftrightarrow \mathrm{C}^{16} \mathrm{O}^{18} \mathrm{O}_{(\mathrm{g})}+\mathrm{H}_{2}^{16} \mathrm{O}_{(\mathrm{l})} \\
\delta^{18} \mathrm{O}_{\mathrm{V}-\text { SMOW }}=\left\{\left[\left({ }^{18} \mathrm{O} /{ }^{16} \mathrm{O}\right)_{\text {sample }}-\left({ }^{18} \mathrm{O} /{ }^{16} \mathrm{O}\right)_{\text {standard }}\right] /\right. \\
\left.\left({ }^{18} \mathrm{O} /{ }^{16} \mathrm{O}\right)_{\text {standard }}\right\} \times 1000(\%)
\end{gathered}
$$

\subsection{3. $\delta(2 H)_{\mathrm{n}}\left(\delta D_{n}\right)$ ethanol determination}

Four (4) online EIM - Modules for continuous flow isotopic analysis, provided by SG Isotech DOO Company, were coupled to High Temperature Conversion Elemental Analyser (pyrolysis based method) peripherals and over interface connected to IRMS instruments in all four laboratories. They were used for determination of $\delta D_{n}$ values in wine ethanol samples. The principle of EIM Module - IRMS is based on the rapid and quantitative intramolecular dehydration of ethanol sample over custom made EIM-catalyst, specifically designed by SG Isotech Company, prior to pyrolysis and high precision isotope ratio measurement during a single analysis.

The ethanol $\delta\left({ }^{2} \mathrm{H}\right)_{n}\left(\delta \mathrm{D}_{\mathrm{n}}\right)$ value, is related to the Ethanol Standard Material AAWES (Afusali Authentic Wine Ethanol Standard) also provided by the SG Isotech Company and expressed as deviation of the relative ratio of non-exchangeable deuterium and hydrogen atoms in internal ethanol standard $(\mathrm{D} / \mathrm{H})_{\mathrm{n}}$ in regard to relative ratio of non-exchangeable deuterium and hydrogen atoms in the AAWES, expressed in parts per $1000(\%)$ on SGI Scale, where AAWES has $\delta \mathrm{D}_{\mathrm{n}}$ value of $-211.89 \%$. Preview of chromatogram obtained by using EIM-Module-IRMS is shown at Fig. 1.

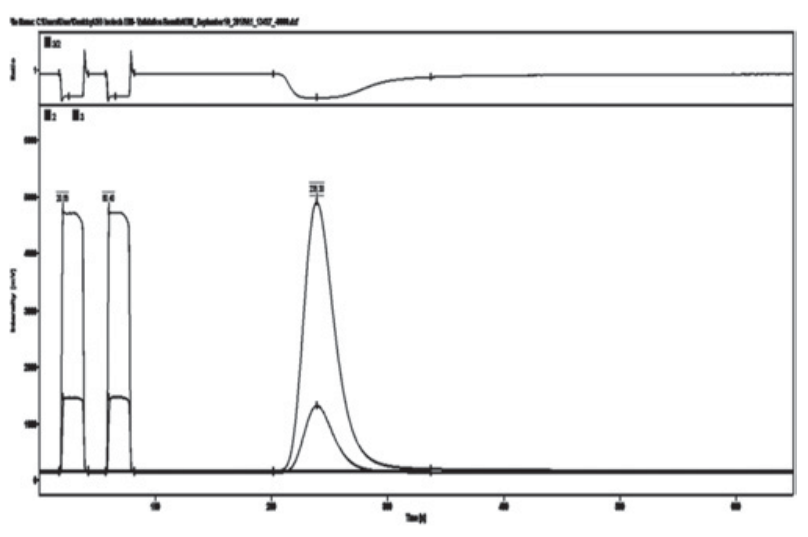

Figure 1. Preview of chromatogram obtained by using EIMModule-IRMS.

\section{Results and discussion}

First we studied the estimation of the repeatability from in-house repeatability testing. The in-house repeatability studies performed in 3 participating laboratories provide data that allows the estimation of the repeatability of the EIM - Module - IRMS method. These inhouse repeatability studies have been performed by measurements of 10 different wine samples - Table 1 (authentic samples and samples with addition of Beet sugar or addition of water prior to alcoholic fermentation).From results shown in Tables 2-5 we have calculated precision limits of the repeatability and reproducibility between 3 labs (Imprint Analytics $\mathrm{GmbH}$, Izotoptech Ltd and C.N.R.I.F.F.I) - Table 6.

The accuracy of measurement is expressed by the precision limits of the repeatability and reproducibility which can be calculated from the sample standard deviation of the test results. The repeatability precision limit ( $r)$ and the reproducibility precision limit (R) are 
calculated as follows:

$$
\begin{gathered}
r=2.8 \times \mathrm{s} r=2.7 \% \\
\mathrm{R}=2.8 \times \mathrm{sR}=2.13 \%
\end{gathered}
$$

The accuracy of the $\delta \mathrm{D}_{\mathrm{n}}$ value in wine ethanol (\%o vs. AAWES) measurement can be summarized as:

- Average inter-laboratory repeatability (r) (as repeatability of measurements): $2.7 \%$

- Average inter-laboratory reproducibility (R) (as reproducibility of measurements): $2.13 \%$

Since the repeatability limit $(r)$ of measurement is $2.7 \%$, this means that for the lower authenticity range limit value of $-215 \%$ vs. AAWES the authenticity limit value (A.L.) is $-217.7 \%$ vs. AAWES. This means that if sample ethanol $\delta \mathrm{D}_{\mathrm{n}}$ value falls in the range from -205 to $-215 \%$ vs. AAWES we can consider it to be authentic and if its ethanol $\delta \mathrm{D}_{\mathrm{n}}$ value is more negative than $-217.7 \%$ vs. AAWES, we can consider that the sample was tempered with by addition of sugar and/or water prior to alcoholic fermentation.

In accordance with observed results and calculated repeatability and reproducibility precision limits between three laboratories, it is concluded that by using EIM Module - IRMS we have successfully detected 6 out of 7 previously prepared adulterated samples:

- DB73-02: $\delta \mathrm{D}_{\mathrm{n}}=-220.86 \%$ (Addition of Beet sugar $(30 \mathrm{~g} / \mathrm{L})$ to grape must prior to alcoholic fermentation);

- DB73-03: $\delta \mathrm{D}_{\mathrm{n}}=-218.16 \%$ (Dilution of grape must with water $(20 \% \mathrm{v} / \mathrm{v})$ prior to alcoholic fermentation);

- DB73-05: $\delta \mathrm{D}_{\mathrm{n}}=-220.38 \%$ (Addition of Beet sugar $(30 \mathrm{~g} / \mathrm{L})$ to grape must prior to alcoholic fermentation);

- DB73-06: $\delta \mathrm{D}_{\mathrm{n}}=-218.10 \%$ (Dilution of grape must with water $(20 \% \mathrm{v} / \mathrm{v})$ prior to alcoholic fermentation);

- DB73-09: $\delta \mathrm{D}_{\mathrm{n}}=-221.07 \%$ (Addition of Beet sugar $(30 \mathrm{~g} / \mathrm{L})$ to grape must prior to alcoholic fermentation);

- DB73-10: $\delta \mathrm{D}_{\mathrm{n}}=-221.76 \%$ (Dilution of grape must with water $(20 \% \mathrm{v} / \mathrm{v})$ prior to alcoholic fermentation);

Further in Table 7 we have detected one adultered wine taken from the Hungarian market - Vino Tinto (Hungary) - table wine, which had $\delta \mathrm{D}_{\mathrm{n}}$ ethanol value of $-229.93 \%$ vs. AAWES. These tests were performed at Izotoptech Ltd in Debrecen, Hungary.

Furthermore, we have tested 3 more wine samples (Table 8), one from Austria and two from Hungary. For all three samples shown to be without added sugar or water, since their $\mathrm{dD}_{\mathrm{n}}$ ethanol values were in natural range $(-212.28 \%,-210.42 \%,-210.30 \%)$. Tests were performed at Imprint Analytics $\mathrm{GmbH}$, Austria.

Values in Table 9 represents the results for $N=19$ wine samples from Serbian wine producers, and also one wine sample from California (Table 9 under no.20), but which was taken from Serbian market. Tests were performed at COIL, Cornell University.

All wine samples, except one, from Serbian wine producers were found to be authentic and without sugar
Table 7. Wine samples from Hungarian market analyzed at

\begin{tabular}{|c|c|c|c|}
\hline \multirow[t]{2}{*}{ No. } & \multirow[t]{2}{*}{ Sample name } & \multicolumn{2}{|c|}{$\begin{array}{c}\text { Ethanol } \delta D_{n} \text { value } \\
(\% \text { vs. AAWES at SGI Scale) }\end{array}$} \\
\hline & & Mean & St.Dev. \\
\hline 1. & Bock - 2 (Hungary) & -212.21 & 0.90 \\
\hline 2. & Gere - 1 (Hungary) & -209.14 & 3.27 \\
\hline 3. & Gere -2 (Hungary) & -204.52 & 1.08 \\
\hline 4. & Tocajicum (Hungary) & -207.50 & 1.65 \\
\hline 5. & Tarapaca (Chile) & -211.43 & 3.27 \\
\hline 6. & Szt. Istvan (Hungary) & -208.81 & 1.41 \\
\hline 7. & Kekfrancos (Hungary) & -214.09 & 3.91 \\
\hline 8. & $\begin{array}{l}\text { Kekfrankos (BB) } \\
\text { (Hungary) }\end{array}$ & -216.91 & 1.89 \\
\hline 9. & $\begin{array}{l}\text { Vino Tinto } \\
\text { (Hungary) - table wine }\end{array}$ & -229.93 & 0.85 \\
\hline
\end{tabular}
Izotoptech Ltd. in Debrecen, Hungary.

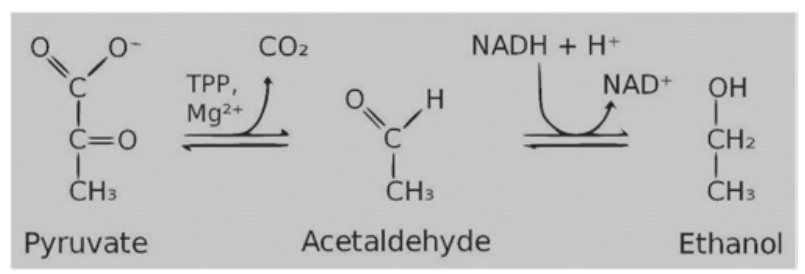

Figure 2. Preview of biochemical mechanism of acetaldehyde reduction to create ethanol in final step of alcoholic fermentation.

and/or water addition (Table 9). It has been detected that one wine sample from Central Srbia Region, PocerskoValjevski subregion, pocersko vineyards - Chardonnay, 2013, white dry wine was produced with illegal addition of sugar and/or water during production, since its $\delta \mathrm{D}_{\mathrm{n}}$ ethanol value was more negative, i.e. $-227.52 \%$ vs. AAWES (Table 9, under no. 4).

Ethanol $\delta \mathrm{D}_{\mathrm{n}}\left(\delta^{2} \mathrm{H}_{\mathrm{n}}\right)$ value gives us also the possibility to detect water addition to grape must prior to alcoholic fermentation since with grape must dilution isotopic profile of fermenting media is changing. On the other hand relative ratio of hydrogen stable isotopes on methylene group of ethanol $(\mathrm{D} / \mathrm{H})_{\text {II }}$ produced in such environment is highly dependent on hydrogen isotopic profile of fermentation media (water).

As it was earlier stated by Matteo Perini and Federica Camin this can be explained by understanding the biochemical mechanism of acetaldehyde reduction to create ethanol, which is the rate determining step of alcoholic fermentation. This final step is done in the presence of ADH (alcohol dehydrogenase) enzyme and $\mathrm{NADH}^{+}$coenzyme which carries hydrogen atom from the fermentation media and helps ADH enzyme to incorporate that proton into acetaldehyde and create ethanol as the final product of alcoholic fermentation (Matteo Perini and Federica Camin, 2013) (Fig. 2).

Furthermore, Eric Jamin et al. purposed and Perini and Camin confirmed those findings that water addition to wine can be detected by comparison of $\delta^{18} \mathrm{O}$ wine water values with $\delta^{18} \mathrm{O}$ wine ethanol values.

Earlier it was confirmed that by comparing the $\delta^{18} \mathrm{O}$ values of the ethanol with $\delta^{18} \mathrm{O}$ of wine water, they obtained a significant $(P<0.001)$ linear relationship $\left(\delta^{18} \mathrm{O}\right.$ water $=0.88 \times \delta^{18} \mathrm{O}$ ethanol -22.65$)$. This means 
Table 8. Wine samples analyzed at Imprint Analytics GmbH.

\begin{tabular}{|c|c|c|c|}
\hline \multirow{2}{*}{ No. } & Sample name & \multicolumn{2}{|c|}{$\begin{array}{c}\text { Ethanol } \delta D_{\mathbf{n}} \text { value } \\
\text { (\%o vs. AAWES at SGI Scale) }\end{array}$} \\
\cline { 3 - 4 } & & Mean & St.Dev. \\
\hline 1. & $\begin{array}{c}\text { Welschriesling, Austria; } 12.0 \% \text { vol, } \\
\text { White wine, dry - 183,199 }\end{array}$ & -212.28 & 0.79 \\
\hline 2. & $\begin{array}{c}\text { Red wine, Cuvee, Hungary; } \\
10.5 \% \text { vol. - 183,200 }\end{array}$ & -210.42 & 1.40 \\
\hline 3. & $\begin{array}{c}\text { Red wine, Portugieser, Hungary; } \\
12.5 \% \text { vol. - 183,201 }\end{array}$ & -210.30 & 2.08 \\
\hline
\end{tabular}

Table 9. Wine samples from Serbian wine producers analyzed at COIL.

\begin{tabular}{|c|c|c|c|c|c|c|c|}
\hline \multirow[t]{2}{*}{ No. } & \multirow[t]{2}{*}{ Sample name } & \multicolumn{2}{|c|}{$\begin{array}{c}\text { Ethanol } \delta^{13} \mathrm{C} \text { value } \\
(\% \text { vs. V-PDB })\end{array}$} & \multicolumn{2}{|c|}{$\begin{array}{c}\text { Ethanol } \delta \mathrm{D}_{\mathrm{n}} \text { value } \\
(\% \text { vs. AAWES } \\
\text { at SGI Scale) }\end{array}$} & \multicolumn{2}{|c|}{$\begin{array}{l}\delta^{18} \mathrm{O} \text { value in wine water } \\
(\% \text { vs. V-SMOW-SLAP) }\end{array}$} \\
\hline & & Mean & St.Dev. & Mean & St.Dev. & Mean & St.Dev. \\
\hline & $\begin{array}{l}\text { Central Serbia Region, Negotinska Krajina subregion - } \\
\text { Crna tamjanika, 2013, Red dry wine }\end{array}$ & -27.93 & 0.13 & -210.75 & 1.20 & 0.98 & 0.20 \\
\hline 2. & $\begin{array}{l}\text { Central Serbia Region, Tri Morave subregion, Župsko } \\
\text { vineyards - Prokupac, 2012, Red dry wine }\end{array}$ & -24.74 & 0.01 & -205.80 & 0.14 & 6.17 & 0.08 \\
\hline 3. & $\begin{array}{l}\text { Region Kosovo i Metohija, južnometohijski subregion, } \\
\text { Orahovačko vineyards, Pinot Noir, 2010, Red dry wine }\end{array}$ & -26.50 & 0.06 & -206.2 & 0.57 & 4.72 & 0.11 \\
\hline 4. & $\begin{array}{l}\text { Central Serbia Region, Pocersko-Valjevski subregion, } \\
\text { pocersko vineyards - Chardonnay, 2013, White dry wine }\end{array}$ & -27.56 & 0.07 & -227.52 & 0.41 & 1.05 & 0.13 \\
\hline 5. & $\begin{array}{l}\text { Region Vojvodina, Sremski subregion, Fruškogorsko vine- } \\
\text { yards - Chardonnay, 2013, White dry wine }\end{array}$ & -27.33 & 0.06 & -213.58 & 2.17 & 1.75 & 0.24 \\
\hline 6. & $\begin{array}{l}\text { Region Vojvodina, Sremski subregion, Fruškogorsko vine- } \\
\text { yards - Pinot Noir, 2013, Red dry wine }\end{array}$ & -28.03 & 0.13 & -207.18 & 0.06 & 2.71 & 0.01 \\
\hline 7. & $\begin{array}{l}\text { Region Vojvodina, Sremski subregion, Fruškogorsko vine- } \\
\text { yards - Riesling, 2013, White dry wine }\end{array}$ & -28.46 & 0.06 & -210.61 & 0.87 & 2.36 & 0.11 \\
\hline 8. & $\begin{array}{l}\text { Region Vojvodina, Sremski subregion, Fruškogorsko vine- } \\
\text { yards - Sauvignon Blanc, 2013, White dry wine }\end{array}$ & -28.27 & 0.02 & -211.39 & 0.35 & 2.25 & 0.14 \\
\hline 9. & $\begin{array}{l}\text { Region Vojvodina, Sremski subregion, Fruškogorsko vine- } \\
\text { yards - Blend of Cabernet Sauvignon, Cabernet Franc, } \\
\text { Merlot, Petit Verdot \& Mersala, 2010, Red dry wine }\end{array}$ & -29.18 & 0.21 & -207.35 & 0.76 & -0.30 & 0.04 \\
\hline 10. & $\begin{array}{l}\text { Region Vojvodina, Sremski subregion, Fruškogorsko vine- } \\
\text { yards - Chardonnay, 2011, White dry wine }\end{array}$ & -29.13 & 0.18 & -214.98 & 0.19 & 3.91 & 0.01 \\
\hline 11. & $\begin{array}{l}\text { Central Serbia Region, Negotinska Krajina subregion - } \\
\text { Cabernet Sauvignon, 2011, Red dry wine }\end{array}$ & -25.95 & 0.06 & -205.50 & 0.14 & 5.34 & 0.01 \\
\hline 12. & $\begin{array}{l}\text { Central Serbia Region, Tri Morave subregion, Župsko } \\
\text { vineyards - Tamnjanika, 2013, White dry wine }\end{array}$ & -25.93 & 0.05 & -216.10 & 0.71 & 1.35 & 0.16 \\
\hline 13. & $\begin{array}{l}\text { Central Serbia Region, Tri Morave subregion, Župsko } \\
\text { vineyards - Tamjanika Župska, 2013, White dry wine }\end{array}$ & -25.38 & 0.28 & -213.9 & 1.13 & 0.90 & 0.06 \\
\hline 14. & $\begin{array}{l}\text { Central Serbia Region, Tri Morave subregion, Župsko } \\
\text { vineyards - Prokupac, 2013, Red dry wine }\end{array}$ & -26.07 & 0.01 & -209.7 & 1.41 & 1.44 & 0.12 \\
\hline 15. & $\begin{array}{l}\text { Central Serbia Region, Šumadijski subregion, Krnjevačko } \\
\text { vineyards - Chardonnay, 2010, White dry wine }\end{array}$ & -29.83 & 0.13 & -209.42 & 3.02 & 1.12 & 0.04 \\
\hline 16. & $\begin{array}{l}\text { Central Serbia Region, Šumadijski subregion, Krnjevačko } \\
\text { vineyards - Sauvignon Blanc, 2009, White dry wine }\end{array}$ & -29.35 & 0.28 & -213.51 & 0.18 & 3.10 & 0.01 \\
\hline 17. & $\begin{array}{l}\text { Central Serbia Region, Šumadijski subregion, Krnjevačko } \\
\text { vineyards - Cabernet Sauvignon Barrique, 2010, Red dry } \\
\text { wine }\end{array}$ & -29.33 & 0.33 & -208.55 & 0.03 & 0.76 & 0.06 \\
\hline \begin{tabular}{|c|}
18. \\
\end{tabular} & $\begin{array}{l}\text { Central Serbia Region, Šumadijski subregion, Kruševačko } \\
\text { vineyards - Chardonnay, 2011, White dry wine }\end{array}$ & -26.33 & 0.02 & -213.94 & 0.66 & 5.37 & 0.05 \\
\hline 19. & $\begin{array}{l}\text { Region Vojvodina, subregion Telečka, Centralnotelečko } \\
\text { vineyards - Bačka Topola - Traminac, 2011, White dry } \\
\text { wine }\end{array}$ & -29.71 & 0.17 & -215.25 & 0.25 & 2.88 & 0.01 \\
\hline 20. & California - Cabernet Sauvignon, 2011, Red dry wine & -29.59 & 0.14 & -207.78 & 0.06 & 3.38 & 0.10 \\
\hline
\end{tabular}


that the correlation is reliable and independent of the matrix and the $\delta^{18} \mathrm{O}$ values of water, therefore generally effective, regardless of the origin and the production year of wine. This is very important because it makes it possible to use this relationship for authenticity control, avoiding analysis of the $\delta^{18} \mathrm{O}$ of ethanol for all the samples in the official wine databank (Reg. CE 555/2008). As the addition of water to wine changes only the $\delta^{18} \mathrm{O}$ of water and not that of ethanol, as here demonstrated the watering of wine changes this relationship, which could go outside the threshold value, even if the water $\delta^{18} \mathrm{O}$ is not outside the limit defined by wine databank (Jamin et al., 2003).

\section{Conclusion}

We have found that with use of isotopic parameters such as $\delta \mathrm{D}_{\mathrm{n}}$ ethanol values, $\delta^{18} \mathrm{O}$ ethanol values and $\delta^{18} \mathrm{O}$ values in wine waters, it is possible to differentiate between two illegal practices in wine production (addition of sugar and addition of water).

$\delta \mathrm{D}_{\mathrm{n}}$ wine ethanol value is a very useful analytical parameter which can indicate if wine is produced by using legal production practices or it was made with addition of sugar or dilution with water prior to alcoholic fermentation. We have purposed that $\delta \mathrm{D}_{\mathrm{n}}$ values of natural wine ethanol should be in range from -205 to $-215 \%$ o vs. AAWES - Afusali Authentic Wine Ethanol Standard at SGI scale. If suspicious sample shows more negative value than $-215 \%$ that fact could indicate that that wine is produced either from enriched grape must or grape must which was diluted with water prior to alcoholic fermentation. Further it should be taken into account that wine ethanol $\delta \mathrm{D}_{\mathrm{n}}$ value scale represents scale of absolute ethanol and it gives information about ethanol's share which originates from botanical source other than grape or ethanol which was produced from sugar with addition of egzo-water. It should be taken into account that the addition of lower amount of egzo-sugar (less than $30 \mathrm{~g} / \mathrm{L}$ ) would not be the same for grape musts with lower and higher content of natural sugar. The initial sugar concentration in grape must is effecting on the mass concentration of added sugar in the final sugar mixture. This would mean that for grape musts with higher natural sugar content (above $220 \mathrm{~g} / \mathrm{L}$ ) the addition of egzo-sugar less than $30 \mathrm{~g} / \mathrm{L}$ would give smaller share of ethanol in overall wine ethanol and thus $\delta \mathrm{D}_{\mathrm{n}}$ wine value could stay, but not for certain, inside the natural $\delta \mathrm{D}_{\mathrm{n}}$ range between -205 and $-215 \%$ vs. AAWES on SGI Scale. This ascertainment would also be depended on the right position of the natural $\delta \mathrm{D}_{\mathrm{n}}$ wine ethanol value inside the natural $\delta \mathrm{D}_{\mathrm{n}}$ wine ethanol range $(-205$ to $-215 \%$ ). For grape must with lower natural sugar content with the addition of egzo-sugar more than $20 \mathrm{~g} / \mathrm{L}, \delta \mathrm{D}_{\mathrm{n}}$ wine ethanol value would be more negative than $-215 \%$ and be detected as such. On the other hand grape musts with higher natural sugar content are not considered to be further enriched with egzo-sugar since it would be more difficult for yeasts to finish alcoholic fermentation and produce dry wine.

Moreover, we have shown that if grape must was diluted with water prior to alcoholic fermentation $\delta D_{n}$ wine ethanol value would be more negative than original value. This fact also depends on several factors such as original position of the natural $\delta \mathrm{D}_{\mathrm{n}}$ wine ethanol value inside the natural $\delta \mathrm{D}_{\mathrm{n}}$ wine ethanol range $(-205$ to
$-215 \%$ ), amount of water added and its isotopic profile (Tables 2-6).

Further differentiation between two illegal practices can be done with correlation of $\delta^{18} \mathrm{O}$ values of ethanol and wine water. Wine samples which are prepared from diluted grape musts are with lower values and outside of prediction interval and detected as such.

We can conclude that with the addition of new analytical parameter $\delta \mathrm{D}_{\mathrm{n}}\left(\delta^{2} \mathrm{H}_{\mathrm{n}}\right)$ in wine ethanol to known ones such as $\delta^{13} \mathrm{C}$ value in wine ethanol and $\delta^{18} \mathrm{O}$ values in wine water and wine ethanol, it opens up the possibility to detect illegal production practices in wine production with better precision (addition of sugar or water dilution), where $\delta D_{n}\left(\delta^{2} H_{n}\right)$ in wine ethanol gives us information about addition of sugar or water, or both, and then by correlating $\delta^{18} \mathrm{O}$ values of wine ethanol and wine water we can further distinguish weather suspicious sample is diluted with water since enriched samples would stay in the predicted area.

\section{References}

[1] Eurostat statistical books (2015 edition). Agriculture, forestry and fishery statistics. Agricultural products 88, ISSN 2363-2488

[2] G. Meloni, J. Swinnen, The political economy of European wine regulations. LICOS Discussion Paper 320/2012. Version: 17 (2012)

[3] Code of Federal Regulations, Title 27 - Alcohol, Tobacco Products and Firearms. Chapter I - Alcohol and tobacco tax and trade bureau, department of the treasury, Subchapter A - alcohol, part 24 - Wine 27 CFR §24.178 and §24.181 (2017)

[4] A. Rossmann, Food Rev. Int. 17, 347 (2001)

[5] S. Kelly, K. Heaton, J. Hoogewerff, Trends Food Sci. Tech. 16, 555 (2005)

[6] G. Calderone, C. Guillou, Food Chem. 106, 1399 (2008)

[7] J.M. Gerard, L.M. Maryvonne, M. Francoise, J.M. Marie, J. Agric. Food Chem. 31, 311 (1983)

[8] Commission Regulation (EC) No 555/2008, Laying down detailed rules for implementing Council Regulation (EC) No 479/2008 on the common organization of the market in wine as regards support programs, trade with third countries, production potential and on controls in the wine sector, Official Journal of the European Union L 170 (2008)

[9] A. Rossmann, F. Reniero, I. Moussa, H.-L. Schmidt, G. Versini, M.H. Merle, Eur. Food Res. Tech. 208, 400 (1999)

[10] E.C. Regulations and amendments: No. 822/97, ${ }^{18} \mathrm{O} /{ }^{16} \mathrm{O}$ of water in wine. Official Journal of European Communities, No. L 117/10 (1997)

[11] J. Dunbar, Zeitschrift für Lebensmittel-Untersuchung und Forschung 174, 355 (1982)

[12] M. Perini, F. Camin, J. Food Sci. 78, C839 (2013)

[13] E. Jamin, R. Guerin, M. Retif, M. Lees, G.J. Martin, J. Agric. Food Chem. 51, 5202 (2003)

[14] S. Epstein, T. Mayeda, Geochim. Cosmochim. Acta. 4, 213 (1953)

[15] C. Monsallier-Bitea, E. Jamin, M. Lees, B.L. Zhang, G.J. Martin, J. Agric. Food Chem. 54, 279 (2006)

[16] I. Smajlović, K.L. Sparks, J.P. Sparks, I. Leskošek Čukalović, S. Jović, Nat. Product Res. 27, 513 (2013) 